\title{
Article \\ Evaluation of Three Biomaterials from Coconut Mesocarp for Use in Water Treatments Polluted with an Anionic Dye
}

\author{
Angel Darío González-Delgado ${ }^{1, *(\mathbb{D})}$, Angel Villabona-Ortíz ${ }^{2}$ and Candelaria Tejada-Tovar ${ }^{2, * \mathbb{C}}$ \\ 1 Nanomaterials and Computer Aided Process Engineering Research Group (NIPAC), Chemical Engineering \\ Department, Universidad de Cartagena, Avenida del Consulado St. 30, Cartagena de Indias 130015, Colombia \\ 2 Process Design and Biomass Utilization Research Group (IDAB), Chemical Engineering Department, \\ Universidad de Cartagena, Avenida del Consulado St. 30, Cartagena de Indias 130015, Colombia; \\ avillabonao@unicartagena.edu.co \\ * Correspondence: agonzalezd1@unicartagena.edu.co (A.D.G.-D.); ctejadat@unicartagena.edu.co (C.T.-T.)
}

check for updates

Citation: González-Delgado, A.D.; Villabona-Ortíz, A.; Tejada-Tovar, C. Evaluation of Three Biomaterials from Coconut Mesocarp for Use in Water Treatments Polluted with an Anionic Dye. Water 2022, 14, 408. https://doi.org/10.3390/w14030408 Academic Editor: Tushar Kanti Sen Received: 29 December 2021 Accepted: 25 January 2022 Published: 29 January 2022

Publisher's Note: MDPI stays neutral with regard to jurisdictional claims in published maps and institutional affiliations.

Copyright: (C) 2022 by the authors. Licensee MDPI, Basel, Switzerland. This article is an open access article distributed under the terms and conditions of the Creative Commons Attribution (CC BY) license (https:// creativecommons.org/licenses/by/ $4.0 /)$.

\begin{abstract}
Coconut consumption leads to the generation of a large number of fibrous residues such as epicarp and mesocarp. In this study, bioadsorbents were prepared from coconut shells (CS), coconut cellulose (CC) and treated coconut cellulose (MCC) with cetyl trimethyl ammonium chloride (CTAC) for the elimination of Congo red (CR) in a watery solution. The impact of the adsorbent quantity $(15,25$ and $35 \mathrm{mg})$ and initial concentration (40, 70 and $100 \mathrm{mg} / \mathrm{L})$ were evaluated. Fourier transform infrared spectra (FTIR) confirmed the existence of $\mathrm{OH}^{-}, \mathrm{C}=\mathrm{O}, \mathrm{COOH}$ and $\mathrm{CH}_{2}$ groups in the adsorbents as well as the deformation of the bands between 3400 and $3800 \mathrm{~cm}^{-1}$ after the adsorption of CR, which was attributed to its capture in the bioadsorbent. From the bromatological analysis, a content of $48.94 \%$ lignin, $35.99 \%$ cellulose and $10.51 \%$ hemicellulose was found. SEM images showed a lignocellulosic essential surface origin for all adsorbents with presence of folds, roughness of an irregular exposed area and fibrous filaments. The average particle size was $0.45 \mathrm{~mm}$ and adsorbents had a mean porosity of 0.58 . Increasing the initial concentration had a beneficial influence on the removal efficiency of CR, achieving a 99.9\% removal with MCC. CS showed slow kinetics in the initial stages whereas CC and MCC achieved 78\% and $99.98 \%$ removal at $120 \mathrm{~min}$, respectively; an equilibrium was reached at 480 and $20 \mathrm{~min}$, respectively. MCC, CC and CS achieved a maximum $q_{e}$ of $256.12 \mathrm{mg} / \mathrm{g}, 121.62 \mathrm{mg} / \mathrm{g}$ and $17.76 \mathrm{mg} / \mathrm{g}$, respectively.
\end{abstract}

Keywords: adsorption; bioadsorbent; cellulose; dye removal; isotherms

\section{Introduction}

Various activities can cause pollution of water resources, mainly anthropogenic activities such as those carried out in industries and their release of waste effluents [1]. Industrial effluents hold in many synthetic toxic colorings generated by pulp, paint, paper, cosmetic, plastic, textile, leather and carpet industries [2]. Congo red is a dye with the presence of azo and sulfonate groups with an aromatic ring and is a widely used damaging dye. This dye has been reported to cause cancer, cellular mutations, teratogenesis, respiratory damage and allergies [3]. Therefore, it is mandatory to remove this highly harmful pollutant from sewage before its final disposal into the water bodies [4].

In order to reduce and remove CR from effluents, several physicochemical methods have been employed such as reverse osmosis [5], adsorption, ion exchange [6], photodegradation [7], coagulation-flocculation [8], sedimentation and ultrafiltration [9]. Adsorption technology has obtained an enormous value for effluent treatment due to its various benefits such as a small expense, a straightforward design, an uncomplicated operation and changeableness over other methods similar to catalytic ozonation [10], Fenton oxidation and photocatalysis [11]. The success of the adsorption technique depends on many operating variables, including the contaminant concentration, adsorbent dosage, $\mathrm{pH}$, contact time, adsorbate-adsorbent interaction and type of adsorbent [12]. Thus, the concern arises 
to produce new adsorbents that are highly available, reusable and economical. Among them, lignocellulosic-based biomasses have received careful interest to prepare workable materials due to its clean, biodegradable and revolving properties [13]. Coconut is a globally distributed and widely consumed food and its mesocarp represents about $50 \%$ of the dry matter generated after coconut harvesting. Although alternative uses have been found, a great quantity of these residues are still considered to be rubbish or are in the open [14].

Cellulose molecules are composed of many hydroxyl groups attributed to their adsorption ability. Nevertheless, cellulose is used raw in the removal of contaminants; its adsorption capacity is lower as well as its selectivity in comparison with modified cellulose. To improve the adsorption capacity of the original cellulose, many cellulose-based adsorbents have been synthetized by chemical modification by adding protons to the surface area $[15,16]$ to increase the electrostatic interactions as well as other interactions between the adsorbent and the contaminant [17]. For removing dyes in an aqueous solution, the adsorbent must have a positive charge. Cationized cellulose is a material in which positive functional groups are added onto its active centers; it shows cationic qualities at different $\mathrm{pH}$ values that favor the adsorption of anionic contaminants.

Quaternary ammonium salts have generally been used to cationize the cellulose surface. Thus, due to the cationic compound in the structure, it can interact with negatively charged materials on the surface. Epichlorohydrin [18], trimethylamine [19], cetyl trimethyl ammonium bromide [20] and tetramethylethylenediamine [21] have all been used as modifier factors for the synthesis of protoned cellulose. Previously, a rice cellulose-based bioadsorbent was made by using hydroxy propyl octadecyl dimethyl ammonium as a modifier, achieving an adsorption capacity of $580.09 \mathrm{mg} / \mathrm{g}$ [17].

In this study, coconut mesocarps were used as precursor for separating cellulose by an alkaline treatment and a bleaching treatment. Cellulose from coconut shells was modified with CTAC to prepare cationized cellulose. The adsorption properties of diazo-anionic dye Congo red (CR) on coconut shells, coconut cellulose and cationized coconut cellulose were studied. The effect of adsorbent dosage, initial concentration and contact time was studied. The equilibrium adsorption behavior was analyzed to understand the adsorption mechanism. It is noteworthy that no studies on the use of this biomass modified with CTAC for dye removal have been reported in the literature; therefore, the contributions of the present study are considered to be essential for filling this gap.

\section{Materials and Methods}

Congo red, analytical grade, was implemented for the preparation of the stock solution. The $\mathrm{pH}$ was measured with $\mathrm{HCl}$ and $\mathrm{NaOH}$ solutions at $0.1 \mathrm{M}$. The measurement of the dyes was performed in a Shimadzu UV/Vis Spectrophotometer (UV 1700 Hach DR 2700). The removal efficiency (\%) was considered to be a response variable and the adsorbent dose $(\mathrm{mg})$, initial contaminant concentration $\left(\mathrm{mg} \mathrm{L}^{-1}\right)$ and contact time (min) as independent variables. The experiments were conducted according to a multilevel factorial design of experiments with three levels of adsorbent dose $\left(5,8\right.$ and $\left.12 \mathrm{mg} \mathrm{L}^{-1}\right)$ and three variations of contaminant concentration $\left(40,70\right.$ and $\left.100 \mathrm{mg} \mathrm{L}^{-1}\right)$.

\subsection{Biomass Pretreatment}

Coconut shells were collected from street vendors in Cartagena (Colombia) and those in the best condition were selected to take advantage of a longer shelf life and to avoid decomposition. The precursor was rinsed with deionized water, dried at $60{ }^{\circ} \mathrm{C}$ until it was a steady mass and reduced in size in a blade mill. A size classification was performed by using stainless steel sieves with opening sizes ranging from $0.8 \mathrm{~mm}$ to $0.355 \mathrm{~mm}$ [22].

\subsection{Cellulose Extraction and Modification}

For the cellulose extraction, the prepared coconut shell was submerged in $500 \mathrm{~mL}$ of $\mathrm{NaOH}$ at $4 \%$ wt. with agitation at $200 \mathrm{rpm}$ and $80{ }^{\circ} \mathrm{C}$ for $2 \mathrm{~h} ; 20 \mathrm{~g}$ of the precursor was submerged in $500 \mathrm{~mL}$ of an $\mathrm{NaOH}$ solution at $4 \% \mathrm{wt}$. with agitation at $200 \mathrm{rpm}$ at $80{ }^{\circ} \mathrm{C}$ for 
$2 \mathrm{~h}$ [23]. The resulting subproduct was washed with distilled water. It was placed in contact with $50 \mathrm{~g}$ of $\mathrm{NaClO}_{2}$ dissolved in $500 \mathrm{~mL}$ of distilled water and $50 \mathrm{~mL}$ of $\mathrm{CH}_{3} \mathrm{COOH}$ with mechanical agitation at room temperature for $24 \mathrm{~h}$. The sediment was then washed with distilled water and dried at $50{ }^{\circ} \mathrm{C}$ to obtain a constant weight.

The cellulose obtained was quaternized using $25 \%$ CTAC. For each $1 \mathrm{~g}$ of cellulose, the volume ratio was $10 \mathrm{~mL}$ of CTAC. The mixture was placed in contact with mechanical agitation at $300 \mathrm{rpm}$ for $24 \mathrm{~h}$ at $25^{\circ} \mathrm{C}$. The resulting sample was washed with distilled water to obtain a $\mathrm{pH}$ of 7.

The bioadsorbents were characterized by an FTIR analysis before and after CR removal using a Perkin Elmer model 1600 series spectrophotometer in the range of 500 to $4500 \mathrm{~cm}^{-1}$ to establish the functional groups involved in the anion adsorption process. The zero charge point $\mathrm{pH}\left(\mathrm{pH}_{\mathrm{PZC}}\right)$ was determined to analyze the charge distribution on the adsorbent surface and its effect on the adsorption capacity [24]. The points of zero charge for the bioadsorbents from the coconut coir were determined by the solid addition method. A total of $50 \mathrm{~mL}$ of water with a $\mathrm{pH}$ varying from 2 to 12 was transferred to a series of $100 \mathrm{~mL}$ conical Erlenmeyers. The $\mathrm{pH}$ of the solutions was adjusted by adding $\mathrm{HCl}$ or $\mathrm{NaOH} 0.1 \mathrm{M}$. The solutions were put under contact with $0.5 \mathrm{~g}$ of each bioadsorbent and immediately securely capped. The suspensions were shaken at $250 \mathrm{rpm}$ for $24 \mathrm{~h}$; after that, the $\mathrm{pH}$ of the supernatant for each Erlenmeyer was noted [25].

\subsection{Adsorption Assays}

The removal assays were performed in a Thermo Scientific orbital shaker (model MAXQ 4450) (Waltham, EE.UU.); $5 \mathrm{~mL}$ of the solution was set in contact with the adsorbent at $250 \mathrm{rpm}$ at room temperature for $24 \mathrm{~h}$. The final RC concentration was measured by infrared spectrophotometry at $427 \mathrm{~nm}$ in a Biobase model BK-UV1900 UV/Vis spectrophotometer [26]. The removal efficiency (E) was determined according to Equation (1):

$$
E[\%]=\frac{\left(C_{0}-C_{f}\right)}{C_{o}} \times 100
$$

where $C_{0}\left(\frac{m g}{L}\right)$ is the initial dye concentration in the solution and $C_{f}\left(\frac{m g}{L}\right)$ is the concentration of the ending of the adsorption tests.

An analysis of variance (ANOVA) was performed in Statgraphics Centurion XVIII.I.II software to determine the statistical significance of the evaluated variables on the dye removal efficiency of CR. The effect of time was evaluated at the best condition of the adsorbent dose and initial concentration. For this, the solution tinted with RC was laid in contact with the bioadsorbent material at $250 \mathrm{rpm}$; samples were collected at 5, 10, 20, 30, 60, $120,240,480,720$ and $1440 \mathrm{~min}$ and the remaining dye concentration was determined [27]. The experimental kinetic data were adjusted to the models shown in Table 1. 
Table 1. Non-linear kinetic models.

\begin{tabular}{|c|c|c|c|}
\hline Model & Equation & & Parameter \\
\hline Pseudo-first order & $q_{t}=q_{e}\left(1-e^{k_{1} t}\right)$ & (2) & $\begin{array}{c}q_{e} \text { and } q_{t}(\mathrm{mg} / \mathrm{g}): \text { adsorption capacities at an } \\
\text { equilibrium and at a certain time. } \\
k_{1}\left(\mathrm{~min}^{-1}\right): \text { Lagergren constant. }\end{array}$ \\
\hline Pseudo-second order & $q_{t}=\frac{t}{\frac{1}{k_{2} q_{e}^{2}}+\frac{t}{q_{e}}}$ & (3) & $\begin{array}{c}k_{2}\left(\mathrm{~g}^{-1} \mathrm{~min}^{-1}\right): \text { pseudo-second order adsorption } \\
\text { constant. }\end{array}$ \\
\hline Elovich & $q_{t}=\frac{1}{\beta} \ln (\alpha \beta)+\frac{1}{\beta} \ln (t)$ & (4) & $\begin{array}{c}\alpha\left(\mathrm{mg} \mathrm{g}^{-1} \mathrm{~min}^{-1}\right) \text { : speed of adsorption at the beginning. } \\
\beta\left(\mathrm{g} \mathrm{mg}^{-1}\right) \text { : desorption constant. } \\
q_{t}(\mathrm{mg} / \mathrm{g}): \text { quantity of chemisorbed pollutant. }\end{array}$ \\
\hline Intraparticle diffusion & $q_{t}=k_{3} t^{0.5}$ & (5) & $\begin{array}{c}q_{t}(\mathrm{mg} / \mathrm{g}): \text { amount of contaminant adsorbed per mass } \\
\text { unit of adsorbent in a time, } t . \\
t(\mathrm{~min}) \text { : time. } \\
k_{3}\left(\mathrm{mg} \mathrm{g}^{-1} \mathrm{~min}^{-1 / 2}\right) \text { : constant intraparticular diffusion. }\end{array}$ \\
\hline
\end{tabular}

\subsection{Adsorption Isotherms}

The adsorption equilibrium study was performed by varying the initial concentration of $\mathrm{RC}(25,50,75,100,125$ and $150 \mathrm{mg} / \mathrm{L})$. The top conditions found during the assays of the adsorbent dosage using the bioadsorbents prepared from coconut mesocarp were $24 \mathrm{~h}$ at $150 \mathrm{rpm}$ and room temperature. The data were modelled by the Langmuir (2) and Freundlich (3) models [28].

The Langmuir model infer that the active sites on an adsorbent surface are similar to each other with an equal reaction energy towards the contaminant without interactions between the adsorbed pollutant and the remaining aquatic media [29].

$$
q_{e}=q \max \frac{b C_{e}}{1+b C_{e}}
$$

where $q_{e}(\mathrm{mg} / \mathrm{g})$ is the concentration of the metal adsorbed on the bioadsorbent, $C_{e}(\mathrm{mg}$ $\left.\mathrm{L}^{-1}\right)$ is the residual concentration of the metal in the solution, $q_{\max }\left(\mathrm{mg} \mathrm{g}^{-1}\right)$ is the maximum adsorption and $\mathrm{b}$ is the ratio between the adsorption/desorption rates.

The Freundlich model assumes that adsorption occurs on a heterogeneous surface with active sites having a different performance from each other and being capable of forming a multilayer [30].

$$
q_{e}=K_{f} C_{e}^{\frac{1}{n}}
$$

where $K_{f}\left(\mathrm{mg} \mathrm{g}^{-1}\right)$ is the Freundlich constant, $\mathrm{n}$ represents the adsorption intensity, $q_{e}$ is the amount of metal adsorbed at an equilibrium and $C_{e}\left(\mathrm{mg} \mathrm{L}^{-1}\right)$ is the residual concentration of metal in the solution.

\section{Results}

3.1. Characterization of the Bioadsorbents

\subsubsection{FTIR Spectrum}

Figure 1 shows the spectra of the bioadsorbents prepared from coconut shells before and after the adsorption of Congo red. 


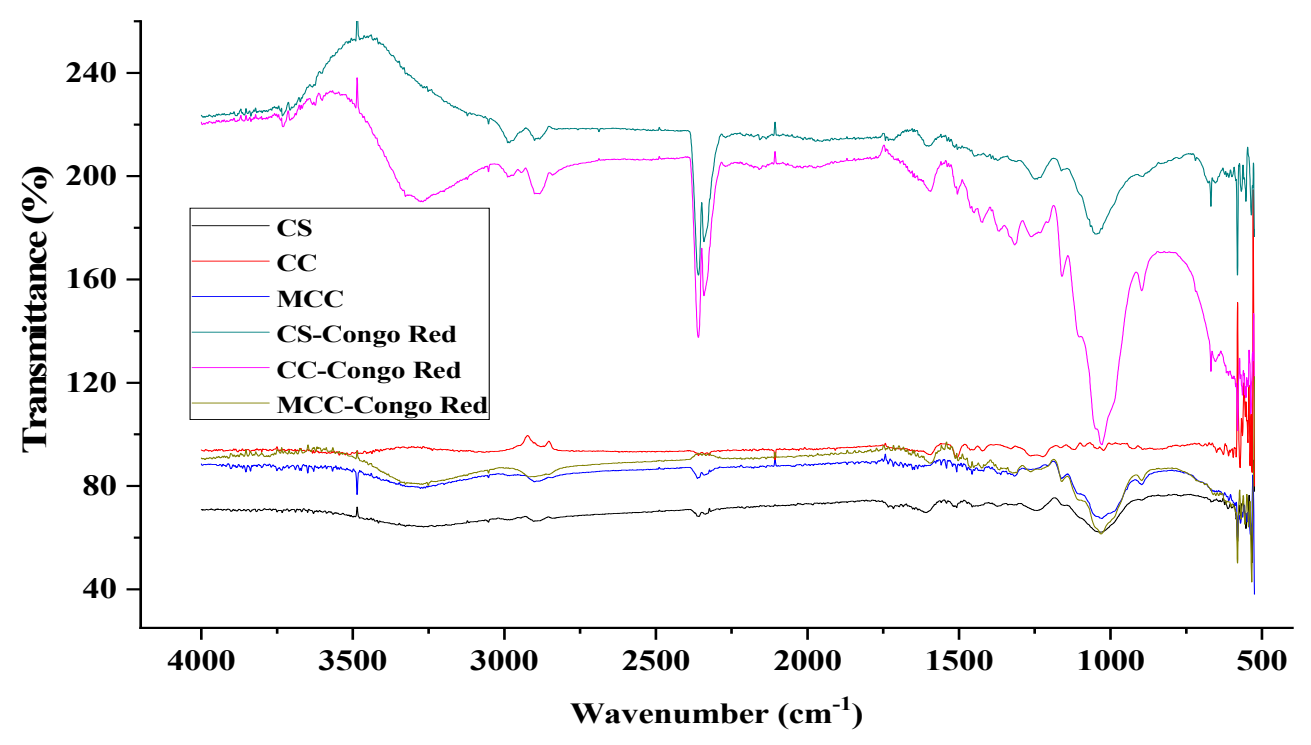

Figure 1. FTIR spectra of coconut shell bioadsorbents before and after Congo red removal.

CS, CC and MCC had similar structures; a pronounced breadth pinnacle was present near $3350 \mathrm{~cm}^{-1}$ of the product, tightening the vibration of the $\mathrm{OH}^{-}, \mathrm{COOH}$ and $\mathrm{NH}_{\mathrm{x}}$ groups matching to the vibration of the functional groups in cellulose and hemicellulose [31]. Between 3400 and $3500 \mathrm{~cm}^{-1}$, the appearance of amines and small carbonyl overtones due to the elongation vibrations of the $\mathrm{O}-\mathrm{H}$ bond were observed [17]. The presence of methoxy groups was also confirmed in the peak at $2904 \mathrm{~cm}^{-1}$; alkynes and carboxylic acids were found between 2000 and $2500 \mathrm{~cm}^{-1}$. The vibration observed from $1733.37 \mathrm{~cm}^{-1}$ was due to the straightening of the $\mathrm{C}=\mathrm{O}$ bonds in carboxylic acids; these peaks were lighter in CC and MCC. The peaks from 1490 to $829 \mathrm{~cm}^{-1}$ were due to the stretching and bending throbbing of $-\mathrm{CH}_{2}$ as well as the $-\mathrm{CH},-\mathrm{OH}$ and $\mathrm{C}-\mathrm{O}$ bonds in cellulose [32]. The peaks in MCC were broader and with a higher intensity, which was attributed to the modification of the structure of the material with respect to CS and CC [33]. After the adsorption tests, there was evidence of a band shift and the disappearance of adsorption peaks, attributed to the capture of the dye in the active adsorption centers of the bioadsorbents such as stretching at 4000-2995 $\mathrm{cm}^{-1}$ and $2900 \mathrm{~cm}^{-1}$ as well as the band expanding between 2300 and $2500 \mathrm{~cm}^{-1}$ and bending between 1635 or $1638 \mathrm{~cm}^{-1}$.

\subsubsection{Point Zero Charge}

Considering that the performance of the adsorbents was highly influenced by the $\mathrm{pH}$, which impacted on the sorbent superficial charge, the degree of ionization and the species of sorbate, $\mathrm{pH}_{\mathrm{PZC}}$, was measured. Figure 2 shows the intersection lines, presenting the behavior $\mathrm{CS}>\mathrm{CC}>\mathrm{MMC}$, when the raw material reported a higher PZC. CC had a $\mathrm{pH}_{\mathrm{PZC}}$ value of 5.88, which was within the $\mathrm{pH}$ range for crude cellulose (5.0-7.0) [34]. When the $\mathrm{pH}$ was lower than $\mathrm{pH}_{\mathrm{PZC}}$, the active centers on the surface were proton-charged and vice versa when the $\mathrm{pH}$ was greater than $\mathrm{pH}_{\mathrm{PZC}}$. Taking into account the nature of anionic dyes, their elimination was also improved at $\mathrm{pH}>\mathrm{pH} \mathrm{PZC}$ for the rise of $\mathrm{H}^{+}$ions. Figure 2 shows that if the cellulose was chemically modified with CTAC, its $\mathrm{pH}_{\mathrm{PZC}}$ decreased slightly to 5.73 , which could be attributed to the formation of acidic functional groups on the carbon surface. It must be pointed out that the surface of the sorbent switched its polarization depending on the $\mathrm{pH}$ value of the solution and to the $\mathrm{pH}_{\mathrm{PZC}}$ of the solid. It was expected that at a lower $\mathrm{pH}$, the sorption of dyes would be enhanced. Thus, in this study, the adsorption test was carried out at $\mathrm{pH} 4$. 


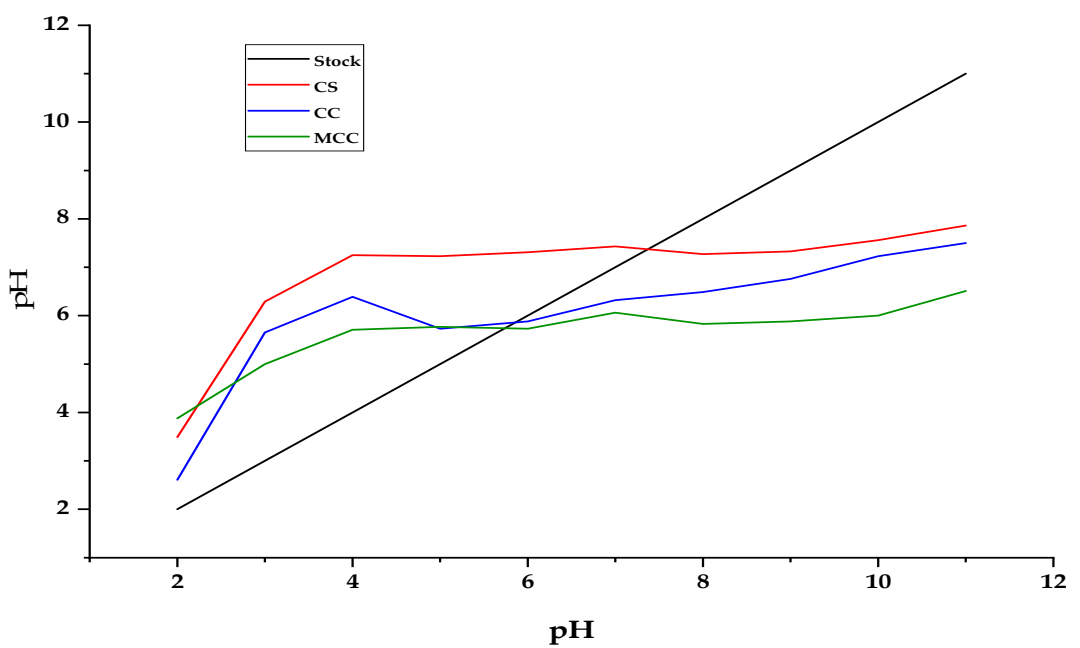

Figure 2. $\mathrm{pH}_{\mathrm{PZC}}$ of bioadsorbents from coconut coir.

\subsubsection{Bromatological and Structural Analysis}

Table 2 shows the compositional bromatological analysis of the coconut mesocarp, which presents a high content of lignin and cellulose typical of lignocellulosic materials. This suggested the presence of active centers that could be used in the capture of pollutants and for the entry of modifying agents. The presence of these compounds in the structure of biomaterials guarantees a large number of hydroxyl, amino and carboxylic groups [31].

Table 2. Coconut husk bromatological analysis.

\begin{tabular}{ccc}
\hline Component & Composition $\%$ & Method \\
\hline Lignin & $48.94 \pm 0.88$ & TAPPI T 203 os-74 \\
Cellulose & $35.99 \pm 0.45$ & TAPPI T 222 om-83 \\
Hemicellulose & $10.51 \pm 0.37$ & TAPPI T 222 om-83 \\
Extractives & $4.56 \pm 0.2$ & TAPPI T 204 D-2 \\
\hline
\end{tabular}

An SEM analysis of the coconut mesocarp (Figure 3a) exhibited the essential superficial characteristics of materials of a lignocellulosic origin where folds and roughness are present with an irregular exposed area and the presence of fibrous filaments with heterogeneous spirals. The fiber filaments are due to the existence of cellulose, hemicellulose and lignin in the structure of the coconut residue; this facilitate the adsorption capacities of the material for the appearance of carboxyl, amino and hydroxyl functional groups, which can retain cationic contaminants due to their net negative electrostatic charge [35].

Cellulose extracted from the coconut mesocarp (CC) showed the presence of lamellar folds due to the removal of the lignin present in the biomass (Figure 3b) [36]. The filaments observed could be explained due to the removal of non-cellulosic components during the $\mathrm{NaOH}$ treatment [37]. The EDS spectrum showed that the elements with the highest presence in CC were carbon $(55.43 \% \mathrm{wt}$.) and oxygen $(43.01 \% \mathrm{wt}$.) with slight traces of sodium $(0.65 \% \mathrm{wt}$.) and chlorine $(0.92 \% \mathrm{wt})$; the absence of magnesium, phosphorus, sulfur and potassium was due to the treatment with $\mathrm{NaOH}$ [36]. After the modification with CTAC, the pronouncement of the folds in the exposed structure of the bioadsorbent was evident [38]. In addition, there was a change in the exposed surface of the material after the modification, increasing the roughness of the material [39]. A similar behavior was found when modifying magnetic biochar with cetyl trimethyl ammonium bromide with an observation that this modification was not evident in the EDS spectrum [40]. Similarly, the modification of cellulose nanocrystals obtained from kenaf with cetyl trimethyl ammonium bromide was also not evident by a SEM-EDS analysis [33]. The mean particle size of CC and MCC was estimated from the SEM images using Image J software and was approxi- 
mately $0.45 \mathrm{~mm}$. Porosity was determined using the procedure proposed by Abdullah and Khairurrijal [41] in which, from the SEM images, the volume below the surface and the volume below a flat surface whose height is equal to the maximum height from any point on the sample surface are calculated using OriginPro ${ }^{\circledR}$ software; following this method, a porosity of around 0.58 was obtained.
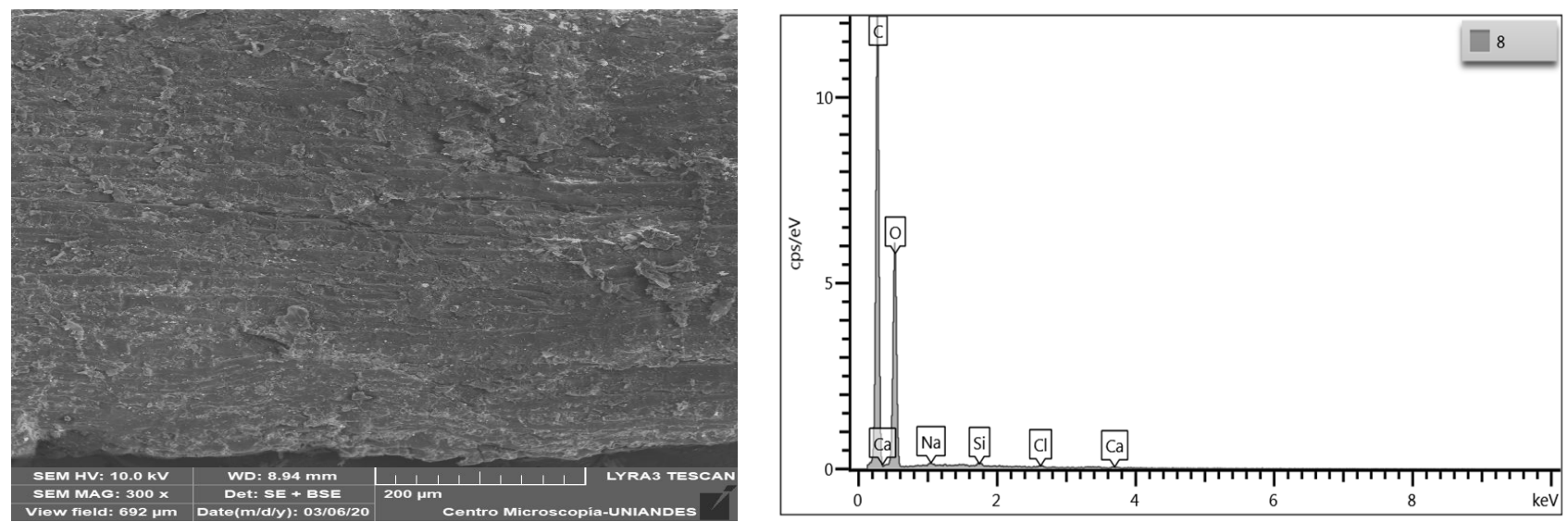

(a)
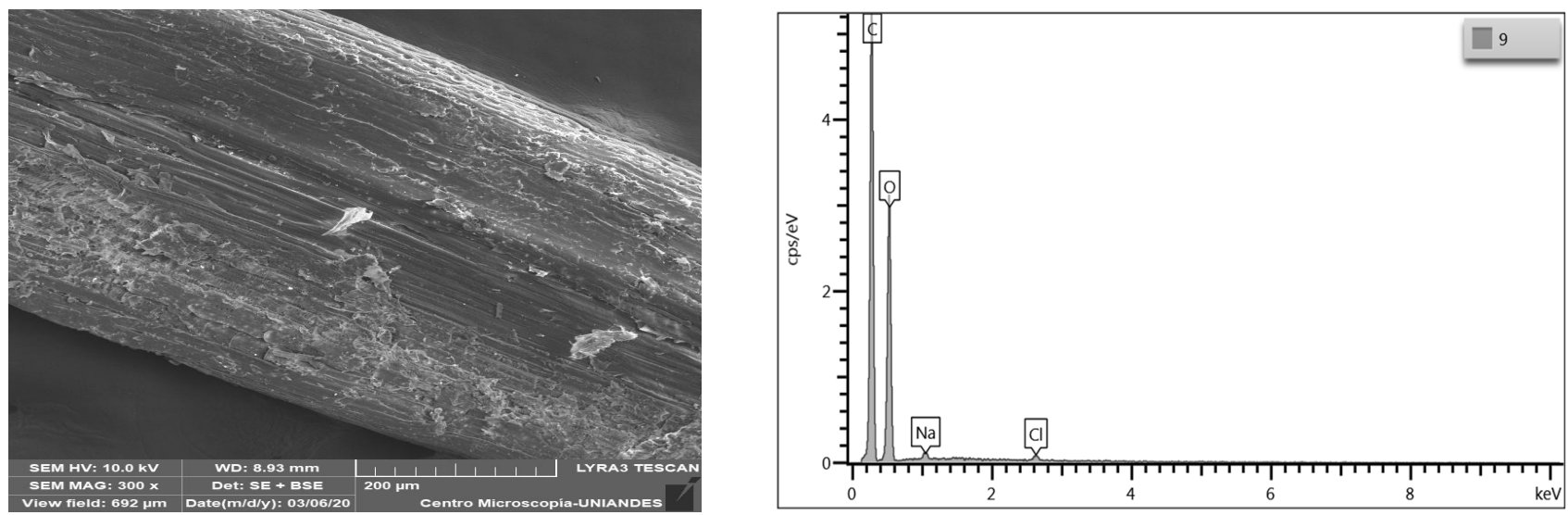

(b)
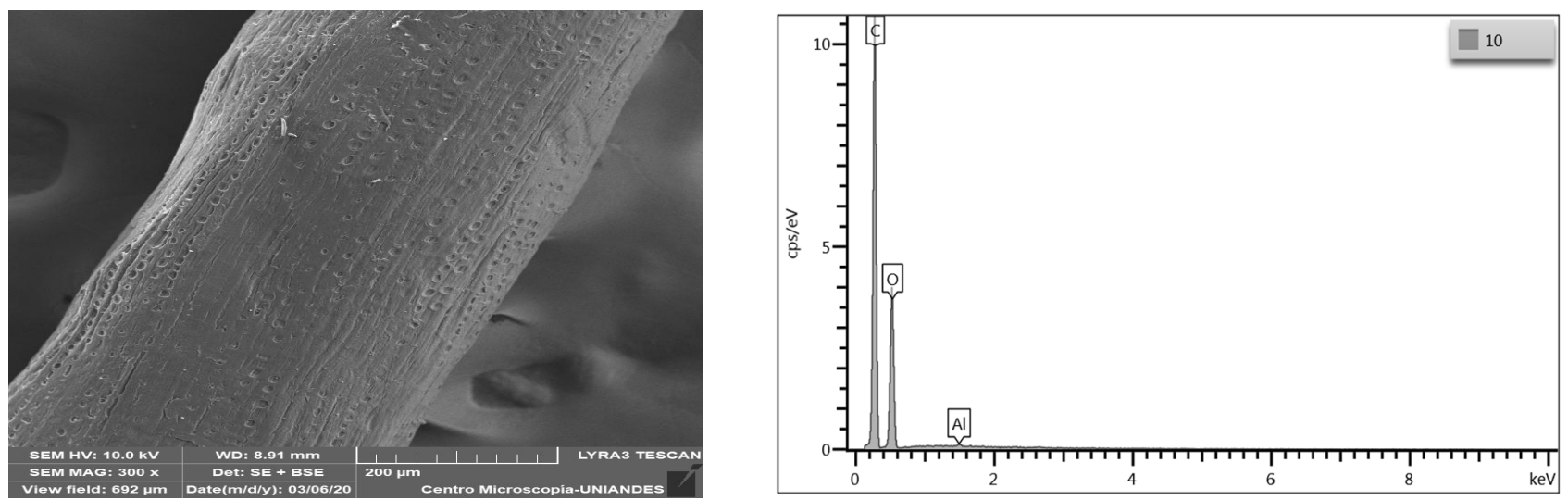

(c)

Figure 3. SEM and EDS micrographs of (a) coconut shell (CS), (b) coconut cellulose (CC) and (c) modified coconut cellulose (MCC). 


\subsection{Congo Red Adsorption Tests}

For a fixed $\mathrm{pH}$ of 4 , the percentage of $\mathrm{CR}$ removal was examined by changing the initial dye concentration and CS, CC and MCC dosage. All three adsorbents evaluated showed a good performance, which could be explained by the reactive nature of the dye [4]. However, MCC showed removal efficiencies $>99.9 \%$ in most cases (Figure 4).

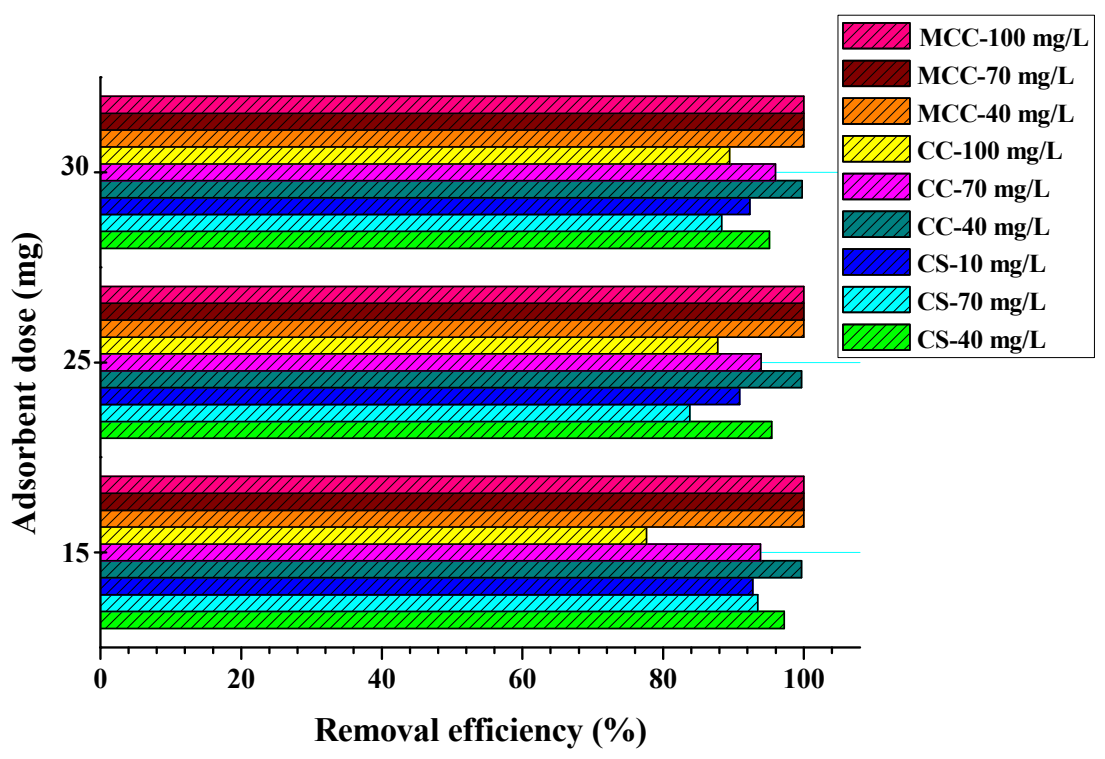

Figure 4. Congo red removal efficiency on coconut shell bioadsorbents at different initial concentrations and adsorbent dosage conditions.

Previously, it was reported that adsorption efficiency is enhanced with an increase in the adsorbent quantity due to the increase in the number of available adsorption centers [42]. A similar behavior was observed when removing CR with a membrane prepared from eggshells modified with $\mathrm{HCl}$ [30] and cellulose microcrystals of oil palm leaves immobilized on PVC [43]. Regarding the initial concentration, no significant effect on the adsorption process was observed; however, when using $\mathrm{CC}$, a $12 \%$ decrease was found when raising the concentration from $40 \mathrm{mg} \mathrm{L}^{-1}(99.65 \%)$ to $100 \mathrm{mg} \mathrm{L}^{-1}$ (77.63\%). Elsewhere, the adsorption capacity presented an increase from $4.8 \mathrm{mg} \mathrm{g}^{-1}$ to $15.5 \mathrm{mg} \mathrm{g}^{-1}$. This could be explained because a greater concentration produced a relevant driving force to exceed the resistances of the RC between the aqueous and solid phases as well as to increase the collisions between the dye ions and the adsorbent, thus improving the adsorption process [44]. Almost similar CR dye adsorption results were obtained when using banana peel [29] as well as biochar and biomass from Cornulaca monacantha [45]. However, the adsorption capacity $\left(q_{e}\right)$ decreased with an increase in the adsorbent dosage and a decrease in the initial dye concentration; this was explained by the fact that there would be an excess of unused adsorption sites and a small amount of dye present to occupy them [46].

The results found in this study were higher than those reported when using cellulose treated with glycidyl trimethyl ammonium chloride [47] and cellulose from pine water functionalized by epichlorohydrin cross-linking and oxidation with periodate to cross-link cellulose dialdehyde [4] where removal efficiencies of $75 \%$ and $85 \%$ were obtained in a day, respectively. The good result of the modified coconut mesocarp cellulose was due to the fact that it is a porous material in which active sites are present. As the maximum removal capacity was achieved using $3 \mathrm{~g} \mathrm{~L}^{-1}$ and $100 \mathrm{mg} \mathrm{L}^{-1}$, in order to guarantee complete adsorption these conditions were chosen to estimate the effect of time over the process. 


\subsection{Statistical Analysis}

The individual interaction of the variables and their quadratic effects were analyzed by ANOVA to determine their statistical influence on RC removal. From the results obtained, it was established that the initial concentration was the variable with the largest significant statistical effect on the removal efficiency [48]. The F-factor values are shown in Table 3 [49]. It can be said that only the initial dye concentration was statistically significant on CC. The F-ratio and $p$-value for CC had a value of zero, which suggested that both variables and their quadratic interactions positively influenced the removal efficiency as observed in Figure 2; as the adsorbent dose and the initial dye concentration increased, the adsorption efficiency increased.

Table 3. ANOVA for the removal efficiency of tartrazine on bioadsorbents prepared from coconut shells.

\begin{tabular}{|c|c|c|c|c|c|c|c|c|c|}
\hline \multirow{3}{*}{ Source } & \multicolumn{9}{|c|}{ Bioadsorbent } \\
\hline & \multicolumn{3}{|c|}{ BS } & \multicolumn{3}{|c|}{$\mathrm{CC}$} & \multicolumn{3}{|c|}{ MCC } \\
\hline & $\begin{array}{l}\text { Sum of } \\
\text { Squares }\end{array}$ & F-Ratio & $\begin{array}{c}p- \\
\text { Value }\end{array}$ & $\begin{array}{l}\text { Sum of } \\
\text { Squares }\end{array}$ & F-Ratio & $\begin{array}{c}p- \\
\text { Value }\end{array}$ & $\begin{array}{l}\text { Sum of } \\
\text { Squares }\end{array}$ & F-Ratio & $\begin{array}{c}p- \\
\text { Value }\end{array}$ \\
\hline A: adsorbent dosage & 9.64 & 1.40 & 0.32 & 33.17 & 6.63 & 0.082 & 0.0 & 0 & 0 \\
\hline B: initial concentration & 23.39 & 3.40 & 0.16 & 326.07 & 65.14 & 0.004 & $6.58 \times 10^{-5}$ & 0 & 0 \\
\hline $\mathrm{AA}$ & 19.73 & 2.87 & 0.19 & 2.29 & 0.46 & 0.55 & 0.0 & 0 & 0 \\
\hline $\mathrm{AB}$ & 0.73 & 0.11 & 0.77 & 34.3434 & 6.86 & 0.08 & 0.0 & 0 & 0 \\
\hline BB & 58.78 & 8.54 & 0.06 & 10.19 & 2.04 & 0.25 & $3.96 \times 10^{-6}$ & 0 & 0 \\
\hline Total error & 20.65 & & & 15.02 & & & 0.0 & & \\
\hline Total (corr.) & 132.91 & & & 421.09 & & & $6.98 \times 10^{-4}$ & & \\
\hline
\end{tabular}

\subsection{Effect of the Contact Time}

The effect of the contact time on the elimination of the CR dye was evaluated during a kinetic study to establish the saturation time and its interaction with the adsorbent [50]. As shown in Figure 5, CS showed a lower performance compared with CC and MCC, achieving a removal efficiency of $89 \%$ at $24 \mathrm{~h}$ without reaching an equilibrium and without any desorption phenomena during the contact time. Likewise, CS showed slow kinetics in the initial min, requiring a long contact time to remove and retain the biomaterial. On the other hand, CC and MCC had prompt adsorption kinetics in the beginning min of the process, reaching $78 \%$ and $99.98 \%$ removal at $120 \mathrm{~min}$; an equilibrium was reached at 480 and $20 \mathrm{~min}$, respectively. The fast equilibrium reached by MCC could be explained by the high disposition of active centers in the material before the experiments and the availability of $\mathrm{RC}$ in the water, achieving $97 \%$ removal in the first $5 \mathrm{~min}$ of the process [51].

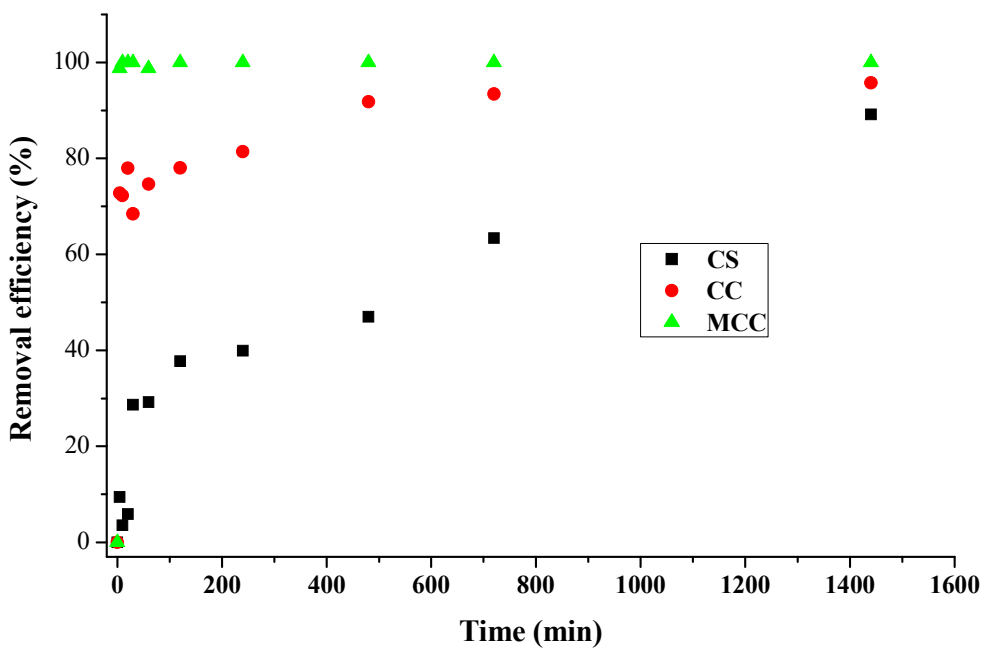

Figure 5. Effect of time on adsorption efficiency of CR. 
Slow CR adsorption kinetics have been reported when using cellulose-chitosan crosslinked foam, reporting a rapid increase in removal in the first $8 \mathrm{~h}$ that continued progressively for $120 \mathrm{~h}$ [52]. When using magnetic cellulose, the equilibrium adsorption time of CR was found to be $3 \mathrm{~h}, 6 \mathrm{~h}$ and $10 \mathrm{~h}$ as the initial concentration increased from 10 to $70 \mathrm{mg} \mathrm{L}^{-1}$, respectively [53]. The kinetics of the adsorption of CR on silica-rich zeolite functionalized with $\mathrm{ZnO}$ [42] was rapid in the beginning phase of removal, as in the present study.

Adsorption can occur due to different mechanisms that establish the way in which the contaminant moves from the solution to the adsorbent and is retained there. Thus, the kinetics establish the intervening steps (intraparticle diffusion, interstitial diffusion, complexation, physisorption and chemisorption, among others) for the elimination of the solute [7]. The adjustment of the experimental kinetic data to the mentioned models in Table 1 is shown in Figure 6.

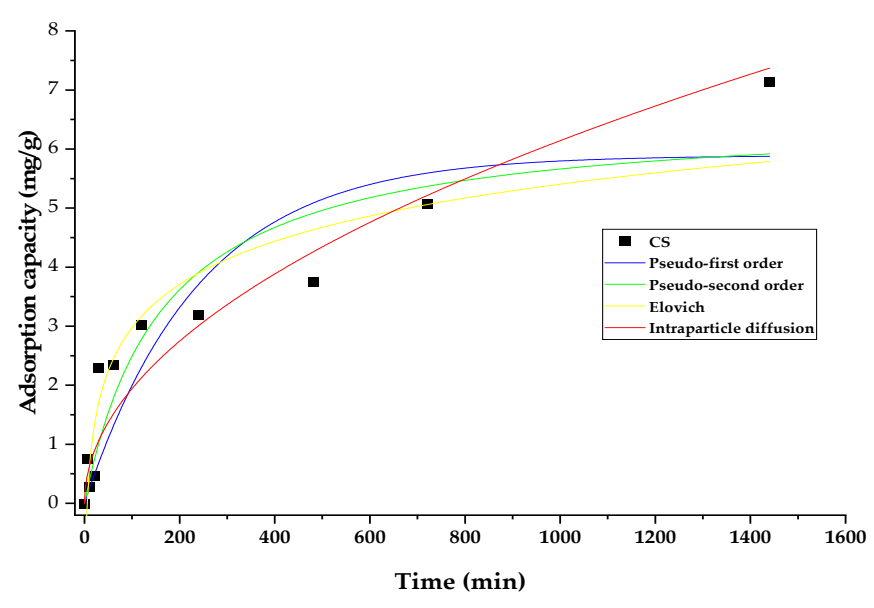

(a)

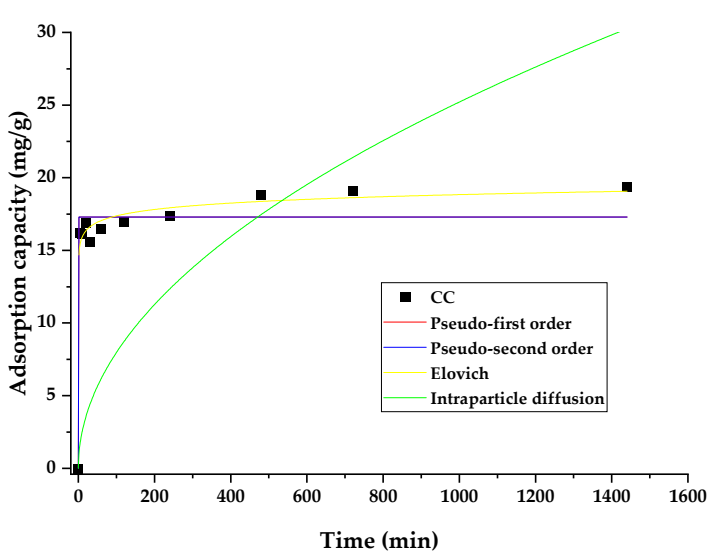

(b)

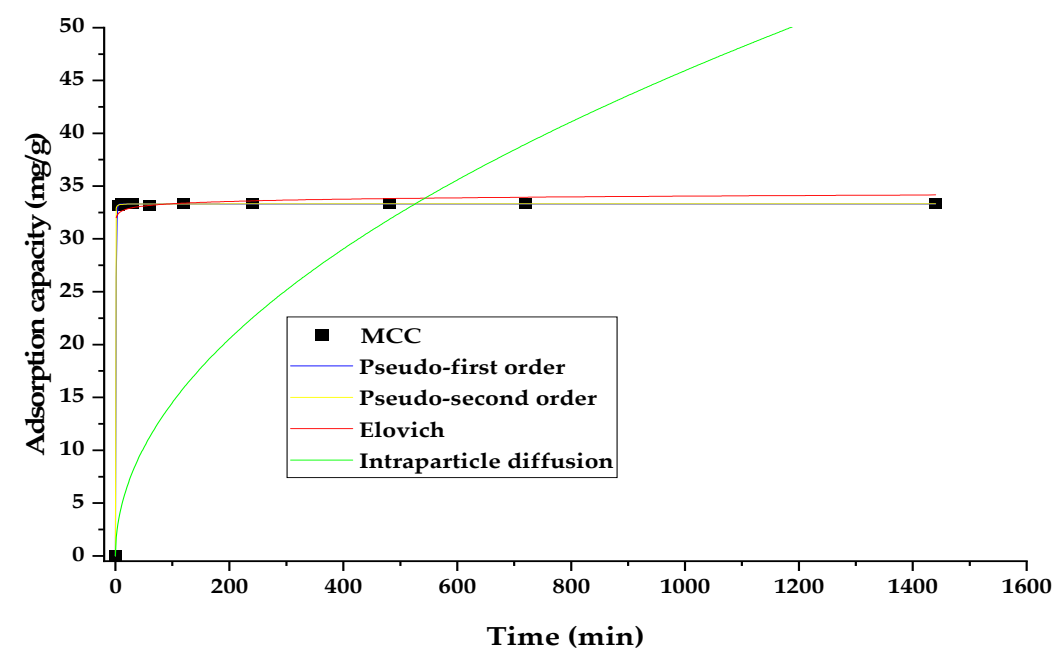

(c)

Figure 6. Non-linear fitting of RC adsorption kinetics on adsorbents from coconut mesocarp for (a) CS, (b) CC and (c) MCC.

In the adsorption kinetics of CR on CS, at around $600 \mathrm{~min}$ a decrease in the amount of adsorbed dye was observed due to the saturation of the removal centers in the biomass [54]. This suggested that during the contaminant removal process, desorption occurred over periods of time, especially when time was prolonged. This provided valuable information 
regarding the lifetime of the adsorbents for their potential implementation as packing in adsorption columns. It was observed that when using CS as an adsorbent, the kinetics were adjusted to the models of pseudo-first order and intraparticle diffusion; therefore, it could be said that the removal of RC on CS was controlled by chemical adsorption through the exchange of ions between the contaminant and the active centers of the bioadsorbent as well as the presence of diffusion from the center of the liquid phase to the solid and through the pores of the bioadsorbent [55]. The fit of the kinetic data to the pseudo-first order model suggested that the rate-limiting step of CR removal was mass transfer [56].

When using CC and MCC, it was found that the intraparticle diffusion model did not present a good fit to the data whereas the pseudo-first order, pseudo-second order and Elovich models fitted the data with a value of $R^{2}>0.93$ with $C C$ and $R^{2}>0.99$ with $\mathrm{MCC}$ in all cases. Fitting to these models suggested that the adsorption was controlled by chemisorption. The fit to the Elovich model assumed that the adsorption surface was heterogeneous. The high value of $\alpha$ indicated that the adsorption occurred rapidly in the initial min (Figure $6 \mathrm{c}$ ). On the contrary, the high value recorded for $\beta$ indicated that desorption could be easily achieved in this system, which facilitated the recovery of the contaminant and the reuse of the biomaterial, especially using MCC [13]. The adsorption rate constants of the pseudo-first and pseudo-second order models expressed that the adsorption process occurred faster in CC; however, the $q_{e}$ behavior was MCC $>C C>C S$ (Table 4).

Table 4. Adjustment parameters of Congo red adsorption on bioadsorbents from coconut mesocarp.

\begin{tabular}{|c|c|c|c|c|}
\hline Model & Parameter & CS & $\mathrm{CC}$ & MCC \\
\hline \multirow{4}{*}{$\begin{array}{l}\text { Pseudo-first } \\
\text { order }\end{array}$} & $q_{e}(\mathrm{mg} / \mathrm{g})$ & 5.892 & 17.291 & 33.313 \\
\hline & $\mathrm{k}_{1}\left(\min ^{-1}\right)$ & 0.004 & 15.187 & 1.087 \\
\hline & $\mathrm{R}^{2}$ & 0.807 & 0.936 & 0.999 \\
\hline & $X^{2}$ & 0.939 & 1.843 & 0.003 \\
\hline \multirow{4}{*}{$\begin{array}{l}\text { Pseudo-second } \\
\text { order }\end{array}$} & $q_{e}(\mathrm{mg} / \mathrm{g})$ & 6.595 & 17.291 & 33.324 \\
\hline & $\mathrm{k}_{2}(\mathrm{~g} / \mathrm{mg} \times \mathrm{min})$ & $9.21 \times 10^{-4}$ & 2.136 & 1.674 \\
\hline & $\mathrm{R}^{2}$ & 0.8674 & 0.936 & 0.999 \\
\hline & $X^{2}$ & 0.646 & 1.843 & 0.003 \\
\hline \multirow{4}{*}{ Elovich } & $\alpha(\mathrm{mg} / \mathrm{g} \times \min )$ & 0.948 & 1.576 & 3.206 \\
\hline & $\beta(\mathrm{g} / \mathrm{mg})$ & 0.177 & 4.929 & $8.049 \times 10^{43}$ \\
\hline & $\mathrm{R}^{2}$ & 0.885 & 0.987 & 0.997 \\
\hline & $X^{2}$ & 0.561 & 0.380 & 0.321 \\
\hline \multirow{3}{*}{$\begin{array}{l}\text { Intraparticle } \\
\text { diffusion }\end{array}$} & $\mathrm{k}_{3}\left(\mathrm{mg} / \mathrm{g} \times \mathrm{s}^{1 / 2}\right)$ & 0.194 & 0.797 & 1.452 \\
\hline & $\mathrm{R}^{2}$ & 0.923 & 30.543 & 15.452 \\
\hline & $X^{2}$ & 0.373 & 101.964 & 449.515 \\
\hline
\end{tabular}

The adjustment of the kinetics to the pseudo-second order could describe the breakup curve in a packed-bed column; this could be done by a general adsorbate material equilibrium to acquire easy mathematical equations for the breakthrough curve in a packed-bed. The obtained equations could then be used to scale-up, design and simulate fixed-bed adsorption columns for the removal of contaminants from effluents considering that practical adsorption systems generally operate in a continuous mode in order to treat large volumes of contaminated water [57].

\subsection{Adsorption Equilibrium Isotherm}

According to the parameters summarized in Table 5, it could be said that the models evaluated did not satisfactorily adjust the adsorption isotherm of RC on CS; this was due to the presence of desorptive phenomena during the process due to the decrease in the concentration of dye in the solution, the increase in the amount of anions on the surface of the adsorbent and the low affinity of CC due to its anionic nature [29]. On the other hand, the adsorption equilibrium of CR on CC and MCC showed a slight fit to the Langmuir model. This suggested that the limiting factor of the process was the physical interactions 
between the adsorbent and the adsorbate, presenting the coating of the biomaterial surface in a monolayer. The active centers had a similar activation energy [58]. From the Langmuir parameter $b$, it could be intuited that the affinity of the adsorbents for the dye presented the sense MCC > CC > CS; the values of $b$ oscillated between 0 and 1 , which indicated a favorability of the process as well as a higher adsorption capacity according to the $q_{\max }$ [59]. Similarly, the parameter $n$ of the Freundlich model suggested a high affinity of CC and MCC for CS as in both cases it was $>1$ whereas that of CS was $<1$ [58].

Table 5. Adsorption isotherm parameters.

\begin{tabular}{ccccc}
\hline \multirow{2}{*}{ Model } & Parameters & \multicolumn{3}{c}{ Congo Red } \\
\cline { 3 - 5 } & & CS & CC & MCC \\
\hline \multirow{3}{*}{ Langmuir } & $q_{\max }(\mathrm{mg} / \mathrm{g})$ & 17.758 & 121.618 & 256.115 \\
& $\mathrm{~b}(\mathrm{~L} / \mathrm{mg})$ & 5.722 & 0.168 & 1.539 \\
& $\mathrm{R}^{2}$ & 0.6363 & 0.814 & 0.009 \\
& $\mathrm{X}^{2}$ & 58.392 & 6.821 & 90.282 \\
Freundlich & $k_{f}(\mathrm{mg} / \mathrm{g})$ & 0.019 & 5.402 & 15.189 \\
& $\mathrm{n}$ & 0.588 & 2.983 & 4.572 \\
& $\mathrm{R}^{2}$ & 0.932 & 0.752 & 0.629 \\
& $\mathrm{X}^{2}$ & 2.505 & 9.137 & 84.519 \\
\hline
\end{tabular}

Table 6 shows the Langmuir parameter $q_{\max }$ data reported for removing CR with adsorbents of a different nature. The results obtained in the present study were in the average range for bioadsorbents of a lignocellulosic origin.

Table 6. $q_{\max }$ of $\mathrm{CR}$ according to the Langmuir model using various adsorbents.

\begin{tabular}{|c|c|c|c|}
\hline Contaminant & Adsorbent & $q_{\max }(\mathrm{mg} / \mathrm{g})$ & Reference \\
\hline \multirow{13}{*}{ Congo Red } & $\begin{array}{c}\text { Cellulose } \\
\text { nanocrystals } \\
\text { modified with cetyl } \\
\text { trimethyl ammonium } \\
\text { bromide }\end{array}$ & 448.43 & [20] \\
\hline & $\begin{array}{c}\text { NaOH-modified } \\
\text { water hyacinth } \\
\text { cellulose nanocrystals }\end{array}$ & 181.8 & [31] \\
\hline & $\begin{array}{l}\text { Hydrogel from } \\
\text { pineapple peel } \\
\text { extracted by } \\
\text { bleaching }\end{array}$ & 138.89 & {$[60]$} \\
\hline & $\mathrm{MCC}$ & 256.115 & \\
\hline & $\mathrm{CC}$ & 121.618 & This study \\
\hline & $\mathrm{CS}$ & 17.758 & \\
\hline & $\begin{array}{l}\text { Coconut residues } \\
\text { Hydrogel from }\end{array}$ & 128.94 & [28] \\
\hline & $\begin{array}{l}\text { water-extracted } \\
\text { pineapple peel }\end{array}$ & 114.19 & {$[60]$} \\
\hline & $\begin{array}{c}\text { Cornulaca-activated } \\
\text { carbon }\end{array}$ & 78.19 & [45] \\
\hline & $\begin{array}{l}\text { Hydrogel made from } \\
\text { pineapple peel } \\
\text { extracted with } \mathrm{NaOH}\end{array}$ & 77.52 & {$[60]$} \\
\hline & $\begin{array}{l}\text { Hydrogel from } \\
\text { pineapple peel } \\
\text { extracted with } \\
\text { bleached } \mathrm{NaOH}\end{array}$ & 75.19 & {$[60]$} \\
\hline & Date palm seeds & 61.72 & [27] \\
\hline & Cornulaca biomass & 43.42 & [45] \\
\hline
\end{tabular}




\section{Conclusions}

From the results found, it was observed that: (1) the adsorbents synthetized had a heterogenous structure with the presence of functional groups such as $\mathrm{OH}$, carboxyl, amino and methyl; after the adsorption treatment, band deformation between 3400 and $3800 \mathrm{~cm}^{-1}$ was evidenced, which was accredited to the capture of RC in the bioadsorbent. (2) Increasing the initial concentration and adsorbent dosage positively affected the removal efficiency, achieving a 99.9\% removal with MCC. (3) CS showed slow kinetics in the initial stages whereas CC and MCC achieved a 78\% and 99.98\% removal at $120 \mathrm{~min}$, respectively; an equilibrium was reached at 480 and $20 \mathrm{~min}$, respectively. (4) The adsorption isotherm did not present a significant fit to the models evaluated due to the possible presence of desorptive phenomena during the process. (5) Coconut cellulose modified with CTAC was a good adsorbent of Congo red in an aqueous solution.

Author Contributions: Conceptualization, C.T.-T., A.V.-O. and A.D.G.-D.; methodology, C.T.-T.; software, A.V.-O.; validation, C.T.-T., A.V.-O. and A.D.G.-D.; formal analysis and investigation, A.V.O.; resources, C.T.-T.; data curation, A.D.G.-D.; writing-original draft preparation, A.V.-O.; writingreview and editing, C.T.-T.; visualization, A.V.-O.; supervision, C.T.-T.; project administration, A.V.-O. and A.D.G.-D.; funding acquisition, C.T.-T. All authors have read and agreed to the published version of the manuscript.

Funding: This research received no external funding.

Data Availability Statement: The data that support the findings of this study are available on request from the corresponding author (C.T.-T.) upon reasonable request.

Acknowledgments: The authors thank to the Universidad de Cartagena for providing the materials, equipment and laboratory facilities required to successfully conclude this research.

Conflicts of Interest: The authors declare no conflict of interest.

\section{References}

1. Bharagava, R.N.; Chowdhary, P. Textile Wastewater Dyes: Toxicity Profile and Treatment Approaches. In Emerging and Eco-Friendly Approaches for Waste Management; Springer: Berlin/Heidelberg, Germany, 2018; pp. 1-435.

2. Padhi, B. Pollution due to synthetic dyes toxicity \& carcinogenicity studies and remediation. Int. J. Environ. Sci. 2012, 3, 940-955.

3. Gray, L.E.; Ostby, J.S.; Kavlock, R.J.; Marshall, R. Gonadal effects of fetal exposure to the azo dye Congo red in mice: Infertility in female but not male offspring. Toxicol. Sci. 1992, 19, 411-422. [CrossRef]

4. Kumari, S.; Mankotia, D.; Chauhan, G.S. Crosslinked cellulose dialdehyde for Congo red removal from its aqueous solutions. J. Environ. Chem. Eng. 2016, 4, 1126-1136. [CrossRef]

5. Rovina, K.; Siddiquee, S.; Shaarani, S.M. A Review of Extraction and Analytical Methods for the Determination of Tartrazine (E 102) in Foodstuffs. Crit. Rev. Anal. Chem. 2017, 47, 309-324. [CrossRef] [PubMed]

6. Jia, Y.; Ding, L.; Ren, P.; Zhong, M.; Ma, J.; Fan, X. Performances and Mechanism of Methyl Orange and Congo Red Adsorbed on the Magnetic Ion-Exchange Resin. J. Chem. Eng. Data 2020, 65, 725-736. [CrossRef]

7. Adam, R.E.; Pozina, G.; Willander, M.; Nur, O. Synthesis of ZnO nanoparticles by co-precipitation method for solar driven photodegradation of Congo red dye at different pH. Photonics Nanostruct.-Fundam. Appl. 2018, 32, 11-18. [CrossRef]

8. Garvasis, J.; Prasad, A.R.; Shamsheera, K.O.; Jaseela, P.K.; Joseph, A. Efficient removal of Congo red from aqueous solutions using phytogenic aluminum sulfate nano coagulant. Mater. Chem. Phys. 2020, 251, 123040. [CrossRef]

9. Hidalgo, A.M.; Gómez, M.; Murcia, M.D.; Serrano, M.; Rodríguez-Schmidt, R.; Escudero, P.A. Behaviour of polysulfone ultrafiltration membrane for dyes removal. Water Sci. Technol. 2018, 77, 2093-2100. [CrossRef] [PubMed]

10. Hu, Q.; Xu, L.; Fu, K.; Zhu, F.; Yang, T.; Yang, T.; Luo, J.; Wu, M.; Yu, D. Ultrastable MOF-based foams for versatile applications. Nano Res. 2021, 1-10. [CrossRef]

11. Qiu, J.; Zhang, X.; Feng, Y.; Zhang, X.; Wang, H.; Yao, J. Modified metal-organic frameworks as photocatalysts. Appl. Catal. B Environ. 2018, 231, 317-342. [CrossRef]

12. Adegoke, K.A.; Bello, O.S. Dye sequestration using agricultural wastes as adsorbents. Water Resour. Ind. 2015, 12, 8-24. [CrossRef]

13. Marques, B.S.; Frantz, T.S.; Sant'Anna Cadaval Junior, T.R.; de Almeida Pinto, L.A.; Dotto, G.L. Adsorption of a textile dye onto piaçava fibers: Kinetic, equilibrium, thermodynamics, and application in simulated effluents. Environ. Sci. Pollut. Res. 2019, 26, 28584-28592. [CrossRef] [PubMed]

14. Roopan, S.M.; Elango, G. Exploitation of Cocos nucifera a non-food toward the biological and nanobiotechnology field. Ind. Crops Prod. 2015, 67, 130-136. [CrossRef] 
15. Sadeghalvad, B.; Khorshidi, N.; Azadmehr, A.; Sillanpää, M. Sorption, mechanism, and behavior of sulfate on various adsorbents: A critical review. Chemosphere 2021, 263, 128064. [CrossRef]

16. Kono, H.; Ogasawara, K.; Kusumoto, R.; Oshima, K.; Hashimoto, H.; Shimizu, Y. Cationic cellulose hydrogels cross-linked by poly (ethylene glycol): Preparation, molecular dynamics, and adsorption of anionic dyes. Carbohydr. Polym. 2016, 152, 170-180. [CrossRef]

17. Jiang, Z.; Hu, D. Molecular mechanism of anionic dyes adsorption on cationized rice husk cellulose from agricultural wastes. J. Mol. Liq. 2019, 276, 105-114. [CrossRef]

18. Orlando, U.S.; Baes, A.U.; Nishijima, W.; Okada, M. Preparation of agricultural residue anion exchangers and its nitrate maximum adsorption capacity. Chemosphere 2002, 48, 1041-1046. [CrossRef]

19. Cao, W.; Dang, Z.; Zhou, X.Q.; Yi, X.Y.; Wu, P.X.; Zhu, N.W.; Lu, G.N. Removal of sulphate from aqueous solution using modified rice straw: Preparation, characterization and adsorption performance. Carbohydr. Polym. 2011, 85, 571-577. [CrossRef]

20. Ranjbar, D.; Raeiszadeh, M.; Lewis, L.; MacLachlan, M.J.; Hatzikiriakos, S.G. Adsorptive removal of Congo red by surfactant modified cellulose nanocrystals: A kinetic, equilibrium, and mechanistic investigation. Cellulose 2020, 27, 3211-3232. [CrossRef]

21. Li, Y.; Xiao, H.; Pan, Y.; Zhang, M.; Jin, Y. Thermal and pH dual-responsive cellulose microfilament spheres for dye removal in single and binary systems. J. Hazard. Mater. 2019, 377, 88-97. [CrossRef]

22. Han, Y.; Cao, X.; Ouyang, X.; Sohi, S.P.; Chen, J. Adsorption kinetics of magnetic biochar derived from peanut hull on removal of $\mathrm{Cr}$ (VI) from aqueous solution: Effects of production conditions and particle size. Chemosphere 2016, 145, 336-341. [CrossRef] [PubMed]

23. Xu, J.; Krietemeyer, E.F.; Boddu, V.M.; Liu, S.X.; Liu, W.C. Production and characterization of cellulose nanofibril (CNF) from agricultural waste corn stover. Carbohydr. Polym. 2018, 192, 202-207. [CrossRef] [PubMed]

24. Herrera-Barros, A.; Tejada-Tovar, C.; Villabona-Ortíz, A.; Gonzalez-Delgado, A.D.; Benitez-Monroy, J. Cd (II) and Ni (II) uptake by novel biosorbent prepared from oil palm residual biomass and Al2O3 nanoparticles. Sustain. Chem. Pharm. 2020, 15, 1-7. [CrossRef]

25. Kosmulski, M. The $\mathrm{pH}$ dependent surface charging and points of zero charge. VII. Update. Adv. Colloid Interface Sci. 2018, 251, 115-138. [CrossRef] [PubMed]

26. Koley, P.; Sakurai, M.; Takei, T.; Aono, M. Facile fabrication of silk protein sericin-mediated hierarchical hydroxyapatite-based bio-hybrid architectures: Excellent adsorption of toxic heavy metals and hazardous dye from wastewater. RSC Adv. 2016, 6 , 86607-86616. [CrossRef]

27. Pathania, D.; Sharma, A.; Siddiqi, Z.M. Removal of congo red dye from aqueous system using Phoenix dactylifera seeds. J. Mol. Liq. 2016, 219, 359-367. [CrossRef]

28. Rani, K.C.; Naik, A.; Chaurasiya, R.S.; Raghavarao, K.S.M.S. Removal of toxic Congo red dye from water employing low-cost coconut residual fiber. Water Sci. Technol. 2017, 75, 2225-2236. [CrossRef]

29. Mondal, N.K.; Kar, S. Potentiality of banana peel for removal of Congo red dye from aqueous solution: Isotherm, kinetics and thermodynamics studies. Appl. Water Sci. 2018, 8, 6. [CrossRef]

30. Parvin, S.; Biswas, B.K.; Rahman, M.A.; Rahman, M.H.; Anik, M.S.; Uddin, M.R. Study on adsorption of Congo red onto chemically modified egg shell membrane. Chemosphere 2019, 236, 124326. [CrossRef]

31. Salahuddin, N.; Abdelwahab, M.A.; Akelah, A.; Elnagar, M. Adsorption of Congo red and crystal violet dyes onto cellulose extracted from Egyptian water hyacinth. Nat. Hazards 2020, 105, 1375-1394. [CrossRef]

32. Chen, X.; Liu, L.; Luo, Z.; Shen, J.; Ni, Q.; Yao, J. Facile preparation of a cellulose-based bioadsorbent modified by hPEI in heterogeneous system for high-efficiency removal of multiple types of dyes. React. Funct. Polym. 2018, 125, 77-83. [CrossRef]

33. Zainuddin, N.; Ahmad, I.; Kargarzadeh, H.; Ramli, S. Hydrophobic kenaf nanocrystalline cellulose for the binding of curcumin. Carbohydr. Polym. 2017, 163, 261-269. [CrossRef] [PubMed]

34. Saha, N.; Saba, A.; Reza, M.T. Effect of hydrothermal carbonization temperature on $\mathrm{pH}$, dissociation constants, and acidic functional groups on hydrochar from cellulose and wood. J. Anal. Appl. Pyrolysis 2019, 137, 138-145. [CrossRef]

35. Aiyesanmi, A.F.; Adebayo, M.A.; Arowojobe, Y. Biosorption of Lead and Cadmium from Aqueous Solution in Single and Binary Systems Using Avocado Pear Exocarp: Effects of Competing Ions. Anal. Lett. 2020, 53, 2501-2516. [CrossRef]

36. Kumar, A.; Negi, Y.S.; Choudhary, V.; Bhardwaj, N.K. Characterization of Cellulose Nanocrystals Produced by Acid-Hydrolysis from Sugarcane Bagasse as Agro-Waste. J. Mater. Phys. Chem. 2014, 2, 1-8. [CrossRef]

37. Beroual, M.; Mehelli, O.; Boumaza, L.; Trache, D.; Tarchoun, A.F.; Derradji, M.; Khimeche, K. Synthesis and Characterization of Microcrystalline Cellulose from Giant Reed Using Different Delignification Processes; Springer: Berlin/Heidelberg, Germany, 2021.

38. Mohamed Pauzan, A.S.; Ahad, N. Biomass Modification Using Cationic Surfactant Cetyltrimethylammonium Bromide (CTAB) to Remove Palm-Based Cooking Oil. J. Chem. 2018, 2018, 5059791. [CrossRef] [PubMed]

39. Bakar, A.H.B.A.; Koay, Y.S.; Ching, Y.C.; Abdullah, L.C.; Choong, T.S.Y.; Alkhatib, M.; Mobarekeh, M.N.; Zahri, N.A.M. Removal of fluoride using quaternized palm kernel shell as adsorbents: Equilibrium isotherms and kinetics studies. BioResources 2016, 11, 4485-4511. [CrossRef]

40. Wang, H.; Wang, S.; Gao, Y. Cetyl trimethyl ammonium bromide modified magnetic biochar from pine nut shells for efficient removal of acid chrome blue K. Bioresour. Technol. 2020, 312, 123564. [CrossRef] [PubMed]

41. Abdullah, M.; Sciences, N. A simple method for determining surface porosity based on SEM images using OriginPro software. Indones. J. Phys. 2009, 20, 2. 
42. Madan, S.; Shaw, R.; Tiwari, S.; Tiwari, S.K. Adsorption dynamics of Congo red dye removal using ZnO functionalized high silica zeolitic particles. Appl. Surf. Sci. 2019, 487, 907-917. [CrossRef]

43. Tan, C.H.C.; Sabar, S.; Hussin, M.H. Development of immobilized microcrystalline cellulose as an effective adsorbent for methylene blue dye removal. S. Afr. J. Chem. Eng. 2018, 26, 11-24. [CrossRef]

44. Jiang, R.; Zhu, H.Y.; Fu, Y.Q.; Zong, E.M.; Jiang, S.T.; Li, J.B.; Zhu, J.Q.; Zhu, Y.Y. Magnetic NiFe2O4/MWCNTs functionalized cellulose bioadsorbent with enhanced adsorption property and rapid separation. Carbohydr. Polym. 2021, 252, 117158. [CrossRef] [PubMed]

45. Sharma, A.; Siddiqui, Z.M.; Dhar, S.; Mehta, P.; Pathania, D. Adsorptive removal of congo red dye (CR) from aqueous solution by Cornulaca monacantha stem and biomass-based activated carbon: Isotherm, kinetics and thermodynamics. Sep. Sci. Technol. 2019, 54, 916-929. [CrossRef]

46. Jaramillo, A.C.; Echavarría, A.M.; Hormaza, A. Diseño Box-Behnken para la optimización de la adsorción del colorante azul ácido sobre residuos de flores. Ing. Y Cienc. 2013, 9, 75-91. [CrossRef]

47. Pei, A.; Butchosa, N.; Berglund, L.A.; Zhou, Q. Surface quaternized cellulose nanofibrils with high water absorbency and adsorption capacity for anionic dyes. Soft Matter 2013, 9, 2047-2055. [CrossRef]

48. Banerjee, S.; Chattopadhyaya, M.C. Adsorption characteristics for the removal of a toxic dye, tartrazine from aqueous solutions by a low cost agricultural by-product. Arab. J. Chem. 2017, 10, S1629-S1638. [CrossRef]

49. Reck, I.M.; Paixão, R.M.; Bergamasco, R.; Vieira, M.F.; Vieira, A.M.S. Removal of tartrazine from aqueous solutions using adsorbents based on activated carbon and Moringa oleifera seeds. J. Clean. Prod. 2018, 171, 85-97. [CrossRef]

50. Wang, J.; Guo, X. Adsorption kinetic models: Physical meanings, applications, and solving methods. J. Hazard. Mater. 2020, 390, 122156. [CrossRef]

51. Litefti, K.; Freire, M.S.; Stitou, M.; González-Álvarez, J. Adsorption of an anionic dye (Congo red) from aqueous solutions by pine bark. Sci. Rep. 2019, 9, 1-11. [CrossRef]

52. Kim, U.J.; Kimura, S.; Wada, M. Highly enhanced adsorption of Congo red onto dialdehyde cellulose-crosslinked cellulosechitosan foam. Carbohydr. Polym. 2019, 214, 294-302. [CrossRef]

53. Zhu, H.Y.; Fu, Y.Q.; Jiang, R.; Jiang, J.H.; Xiao, L.; Zeng, G.M.; Zhao, S.L.; Wang, Y. Adsorption removal of congo red onto magnetic cellulose/Fe3O4/activated carbon composite: Equilibrium, kinetic and thermodynamic studies. Chem. Eng. J. 2011, 173, 494-502. [CrossRef]

54. Aoopngan, C.; Nonkumwong, J.; Phumying, S.; Promjantuek, W.; Maensiri, S.; Noisa, P.; Pinitsoontorn, S.; Ananta, S.; Srisombat, L. Amine-Functionalized and Hydroxyl-Functionalized Magnesium Ferrite Nanoparticles for Congo Red Adsorption. ACS Appl. Nano Mater. 2019, 2, 5329-5341. [CrossRef]

55. William Kajjumba, G.; Emik, S.; Öngen, A.; Kurtulus Özcan, H.; Aydın, S. Modelling of Adsorption Kinetic Processes-Errors, Theory and Application. Advanced Sorption Process Application. 2019, 187-205. [CrossRef]

56. Wang, H.; Shen, H.; Shen, C.; Li, Y.; Ying, Z.; Duan, Y. Kinetics and Mechanism Study of Mercury Adsorption by Activated Carbon in Wet Oxy-Fuel Conditions. Energy Fuels 2019, 33, 1344-1353. [CrossRef]

57. Das, G.K.; Chatterjee, S. Use of Kinetic Models for Correlating Adsorbate Breakthrough in a Fixed Bed of Use of Kinetic Models for Correlating Adsorbate Breakthrough in a Fixed Bed of Adsorbent. In Proceedings of the ChemCon, Kolkata, India, 27-30 December 2007.

58. Gautam, R.K.; Gautam, P.K.; Banerjee, S.; Rawat, V.; Soni, S.; Sharma, S.K.; Chattopadhyaya, M.C. Removal of tartrazine by activated carbon biosorbents of Lantana camara: Kinetics, equilibrium modeling and spectroscopic analysis. J. Environ. Chem. Eng. 2015, 3, 79-88. [CrossRef]

59. Zhang, Y.; Song, X.; Xu, Y.; Shen, H.; Kong, X.; Xu, H. Utilization of wheat bran for producing activated carbon with high specific surface area via $\mathrm{NaOH}$ activation using industrial furnace. J. Clean. Prod. 2019, 210, 366-375. [CrossRef]

60. Dai, H.; Huang, Y.; Zhang, H.; Ma, L.; Huang, H.; Wu, J.; Zhang, Y. Direct fabrication of hierarchically processed pineapple peel hydrogels for efficient Congo red adsorption. Carbohydr. Polym. 2019, 19, 115599. [CrossRef] 